\title{
Writing Techniques in the English Love and Lyric Poems
}

\author{
Xiaoying Liu \\ XianYang Normal University \\ E-mail: xiaoliu1964@163.com
}

Fund Item: Key Science Research Item Sponsored by XianYang Normal University (05XSYK110)

\begin{abstract}
In the poetry creation, poets use many different writing techniques. This paper expounds the image expressions in British love poems and lyrics from four aspects: description, symbolism, figure of speech and personification.

Man has been singing for love since written language was invented. Love has been the eternal subject theme of poems and become perpetual singing. Many poets also worship nature and sing for nature. In order to express their feelings and emotions, poets at all times and in all countries pay much attention to using image expressions and creation in their poems. There are no poems without images. Words are carriers of images. Although poets are in different times, they have the similar writing techniques, we can still find the same or similar image expressions from different poems of different poets. This paper will analyze image expressions in British love poems and lyrical poems from four aspects --description, symbolism, figure of speech and personification.
\end{abstract}

Keywords: Poet, Image expressing

\section{Description}

This kind of image expression is similar to the line drawing in traditional ink and brush style in painting. It strengthens the direct image expression through the senses. The purpose of this image expression is that the poets' feelings and emotions are perceived directly by means of objects. The British famous poet, P.B. Shelley wrote a poem---Love's Philosophy, where the author uses a series of descriptive images, such as boundless sea and sky, the sun, the moon and the stars, mountains and rivers, grass and trees. He shows that all living things in natural world depend on one another, which reflects the poet's subjective impressions."What are all these kissings worth./If thou kiss not me?"From these two sentences we can see the author's cordial love for his sweet heart.

In Shelley's another poem-“Music, When soft voices die", he also uses many descriptive images. Soft voices die, but music vibrates in the memory, sweet violets sicken, but their odors live within the sense. These two images exist in the poet's deep affection, which is just diverged from these two images. The tender singing will die one day. The beautiful flowers will wither at last, only love can last forever.

Christian Rossetti is a famous female poet in Britain. One of her short poems "Song" includes many descriptive images, for example, roses, laurel, an ivy branch, violets, bay, withered leaves, especially the use of "withered leaves" is very successful.

Oh roses for the flush of youth,/And laurel for the perfect prime,/

But pluck an ivy branch for me/ Groum old before my timel

Oh violets for the grave of youth,/And bay for those dead in their prime,/

Give me the withered leaves 1 chose/Before in the old time./

The poet sends "violets" to youth, and "laurel" to middle aged people, but leaves herself "the withered leaves". We can see the loss of love leaves agony in her mental from "the withered leaves". For her lover's happiness, she would rather endure the severe suffering from emotion all by herself. "The withered leaves" indicates her kind heartedness.

Robert Frost, a famous pastoral poet in England, creates different images by description in his poem--- Stopping by Woods on a Snowy Evening. The basic image of this poem is a snowy scene that the speaker views and a series of implicit questions that the scene and his own action as he moves at night. The speaker opens with a question: who owns the woods, the second and third stanza raise implicit questions and the final stanza gives the answer to the question why 
he stopped by the woods: he was attract by the dark beauty of the woods and by the snowy night. The author describes the dark beauty of the woods and the snowy night through a sequence of images. The images in the poem can be divided into two kinds: visual images (e.g. woods, house, village, harness bell, snow, lake) and auditory images (e.g. shake of bells, the sweep of easy winds and downy flake). They correspond to the sensory feelings of the poet as well as the readers, and therefore creative vividness.

\section{Symbolism}

The use of symbols represents real things, feelings, etc. The images created by symbolism are very complicated. The character of symbolism is to express the theme of the poem through implication and inspiring readers to associate something in their mind. In Lord Tennyson's famous poem---"Break, Break, Break," the author uses "gold gray stones Break" to symbolize the poet's broken heart.

Break, break, break, / At the foot of thy crags, O sea!

But the tender grace of a day that is dead / Will never come back to me.

In Shelley' s "the cloud" we can read between the eight lines in the first part that the cloud brings happiness to others and the world, since it, being as rain, brings fresh showers for the thirsting flowers, bears light shade for the leaves and shakes dews on the buds. But in the form of hail, it beats violently on the earth, making the green plain white and going away vividly in the following four lines, that the cloud could be changeable and could change the surroundings at the same time. It symbolizes that the evil society should be got rid of.

In the fifth part, the bow is described as the triumphal arch, hanging like a roof, changing all the storms and something like that and then bringing peace on earth. The million-colored bow indicates the sun shine again after the rain, which then symbolizes that a new scene replacing the old.

The short lyric poem To the Cuckoo by William Wordsworth, is most frequently anthologized and considered as a masterpiece of lyricism in English. As one of the most typical samples of lyrical balladry, this short verse express the poetic persona's intense but pure emotion of delight in hearing the "blessed bird's' echoing singing and his identification with the nature. In the poem, the cuckoo is poeticized and made eternal, as a symbol to bridge the time and space, the past and the present, nature and humanity, hope and reality, love and remembrance. The cuckoo is 'no bird' but everything of the persona's ideal "still longed foe" and of his keen desire to be in oneness with the nature.

\section{Figures of speech}

From the form of expression in poems, the figure of speech can be divided into two categories -simile and metaphor.

1. Simile - the use of comparison of one thing to another, also an expression making a comparison in the imagination between two things. In love poems writers often use a direct, obvious simile to specify the abstract love. The images structured in this way are vivid, distinct and true.

One of the famous love poems is R. Burns' "A RED. RED Rose". In the poem, Burns compares his sweetheart to "a red rose" and "sweet melody".

O my luve's like a red, red rose, / That's newly sprung in June;

O my lure's like the melodie, /That's sweetly played in tune.

Burns also uses "the seas gang dry, the rocks melt wi' the sun" as a simile to express his heart will always remain loyal to his sweetheart.

C. G.Rossetti compares her love to"a singing Bird" "an apple tree", "a rainbow bell" in her poem" A Birthday".

My heart is like a singing bird / Whose nest is in a watered shoot./

My heart is like an apple tree/ Whose boughs are bent with thickest fruit/

My heart is like rainbow shell / That paddles in a halcyon sea./

These three similes express the poet's happiness and richness of the heart.

\section{Metaphor}

Metaphor is words to indicate something different from the literal meaning. An indirect and covert figure of speech is used to specify the abstract love. The character common to simile and metaphor is that both of them create an atmosphere through contrasts and comparing something in common of the two different things. The difference lies in that simile points out something in common of the two different things, while metaphor implies common of the subject and reference in the image. In one poem of Lord Tennyson "O Swallow, Swallow", the author expresses his love indirectly with the aid of swallow and creates images of a young man pursuing love and having honest quality. Although the title of the poem is "Swallow", yet in fact none of the sentences is used to write about the swallow.

In Spenser's poem “Amoretti”. He compares his sweetheart's eyes to saphyres, her lips to rubies, her teeth to pearls etc. 
to express his love feelings.

In the fourth part of P.B. Shelley's "The Cloud", the beauty of fog is myth-like. It's like a woolen carpet in the sky, on which a maiden, the moon, is strolling gently. Once she breaks the carpet, it will fall as dewdrops, glistening in the morning light and each of the dewdrops reflects the luster of the moon and the stars, which can be seam twinkling like golden bees only when the carpet is broken. The moon's gliding on the fleece-like floor, and her breaking the woof of the tent, the star's peeing, the strips of the sky's falling and its being paved with the moon and stars are all metaphors, appropriate and vivid, unfolding and enchanting scenery before our eyes.

\section{Personification}

Personification is the representation of a thing or abstraction in the form of a person as in art. It is one of the simplest ways to make ideas concrete. Using personification in poetry writing. Readers can see how abstract notions are made human, how human qualities are given to abstractions, inanimate objects, and nonhuman beings so as to be familiarized and better understood. In other words, one's love is often invented to be a person or an object, and bestowed on people's thoughts, feelings, behaviors, voices, personality, interest and so on. In William Wordsworth"I Wandered Lonely as A Cloud." he uses the technique of personification. In the first stanza he sees"a crowd of golden daffodils/Fluttering and dancing in the breeze." In the second stanza the author endows the daffodils with pleasure of humanity by giving the rein to his imagination. Many daffodils stretched in never-ending line along the margin of a bay"just like" stars that shine and twinkle on the milky way. "This stanza has rich flavor of life as well as simple languages. The author not only describes the beauty of the daffodils but also regards them as something alive which has the same spirit and personality as himself.

In her poem---Because I could Not Stop for Death, Emily Dickinson describes death as a kind gentleman. She uses "kindly", "civility" objectifying death as a genteel and courtly driver, who is made to serve the end of "Immortality". That "kindly", "civility" is used for the depiction of Death shows the author's attitude towards death "Immorality" is also personified in this poem, which can be seen from "The Carriage held but just ourselves---And Immortality"

"The Miller's Daughter" was written by Lord Tennyson. In this poem the author also adopts the technique of personification. Life is bestowed on "jewel, girdle and necklace". "Jewel trembles at her ear"hid in riglets day and night," "touch her neck so warm and white."

The classification of the above four image expressions is relative, and rough, and it results from the convenience of observations and analyses. In the actual poem writing, these four techniques are often used at the same time and are not easy to be separated from one another.

\section{References}

An, Xiuhua \& Zhu, Chaohui. (2007). A B C to English Poetry. Shanghai: Donghua University Publishing House.

Gang Sui. (2003). Poetry and Fiction Writing in English: a Guidebook. Beijing: People's Publishing House.

Luo. Xuanmin. (2004). Appreciation of English and American Literature (Essay \& Poetry). Beijing: Qinghua University Publishing House.

Paul Procter. (1988). Longman Dictionary.

Wang, Zuoliang. (1993). Selection of British Poems. Shanghai: Shanghai Translation Publishing House.

Wu, Weiren. (1997). History and Selected Readings in British Literature. Beijing: Foreign Language Teaching and Research Press. 